\title{
VIGOR TESTS IN SEEDS CREOLE OF Phaseolus lunatus L.
}

\section{TESTES DE VIGOR EM SEMENTES CRIOULAS DE Phaseolus lunatus L.}

\begin{abstract}
Maria das Graças Rodrigues do NASCIMENTO ${ }^{1}$; Maria Lúcia Maurício da SILVA²; Edna Ursulino ALVES ${ }^{3}$; Caroline Marques RODRIGUES ${ }^{4}$; Maria Joelma da SILVA ${ }^{5}$

1. Universidade Federal da Paraíba, Campus de Areia, Departamento de Fitotecnia, Areia, PB, Brasil. graca.agronomia@gmail.com; 2. Universidade Federal da Paraíba, Campus de Areia, Departamento de Fitotecnia, Areia, PB, Brasil; 3. Universidade Federal da Paraíba, Campus de Areia, Departamento de Fitotecnia, Areia, PB, Brasil. ursulinoalves@ hotmail.com; 4. Universidade Federal Rural de Pernambuco, UFRPE, Garanhuns, PE, Brasil; 5. Universidade Federal da Paraíba, Campus de Areia, Departamento de Fitotecnia, Areia,
\end{abstract} PB, Brasil.

\begin{abstract}
Seeds with a good physiological quality are essential to high productivity. However, for some seeds, Phaseolus lunatus L., the viability and vigor analyze show deficiency in quality. This work aimed to evaluate the physiological quality of Phaseolus lunatus L. seeds using several vigor tests. The study was realized at the Laboratory of Seed Analysis of the Agricultural Sciences Center of the Federal University of Paraíba, in Areia - PB, Brazil. We used seeds from five cultivars of P. lunatus (Branca, Orelha de Vó, Cearense, Rosinha, and Roxinha). To determine the physiological quality, we measured the water content, the viability and vigor test (germination, emergence, electrical conductivity, tetrazolium, first germination count and emergence, seedling length and dry mass). We used a completely randomized design for seeds evaluation, and the field test was performed in randomized blocks. The water content of $P$. lunatus did not differ among the cultivars, indicating a uniformity in the percentage of moisture. Also, the percentage and speed of emergency and the dry mass of seedlings did not differ among the varieties. The tetrazolium and electrical conductivity tests indicated that Rosinha cultivar had the worst viability concerning the other cultivars, showing a low percentage of living tissue and lower electrical conductivity. The seeds of Roxinha cultivar had the better physiological quality, and the Cearense cultivar had the worst quality evaluation. We recommend the tetrazolium test but not the electrical conductivity test to evaluate the vigor of $P$. lunatus.
\end{abstract}

KEYWORDS: Seed analysis. Tetrazolium. Electrical conductivity.

\section{INTRODUCTION}

The use of high-quality seeds is the basis for raising agricultural productivity. Therefore, the physiological component of seed quality is the subject of numerous researchers since there is a series of degenerative changes after their maturity (BRAGA JUNIOR et al., 2011).

The physiological aspect emphasizes that seed performance in the field is affected not only by its physiological quality but also by the genetic, physical, and health attributes that determine the level of quality of a seed lot (MARTINS et al., 2007). The Rules for Seed Analysis (BRASIL, 2009) recommend the standard germination test to evaluate the viability, in which the best favorable environmental conditions are offered to the seeds to obtain the maximum possible germination (SANTOS, 2010). Thus, knowing the conditions that provide fast and uniform seed germination is essential for sowing and reduce the care by the farmers (PACHECO et al. 2006).

The identification of the events that lead to germination loss is one of the main research challenges (SANTOS et al., 2004). Therefore, the efficiency of the test in evaluating the vigor and viability of the seeds is related to the development of an adequate methodology for each species, defining the most appropriate conditions for the preparation, preconditioning, and coloring of the seeds (BHERING et al., 2005).

Phaseolus lunatus L., known as lima beans, and also called as feijoal, bonge, bitter mangalô, fava-belém, lima-terra, bean-espadinho, depending on the region (LOPES et al., 2010) is responsible for more than $95 \%$ of Brazilian production, reaching in 2013 a planted area of 25,542 hectares and production of 7,957 tons (IBGE, 2015). The lima bean has a relevant economic and social importance in Brazil, due to its rusticity with a prolonged harvest carried out during the dry period (AZEVEDO et al., 2003). In the Northeast, lima beans are an important alternative of income and a food source for the population (FRANÇA NETO et al., 2007) besides its high protein content (SOARES et al., 2010).

Considering the importance of lima bean as an economic and food source, this study aimed to evaluate the physiological quality of seeds from 
different cultivars of Phaseolus lunatus L. by vigor tests.

\section{MATERIAL AND METHODS}

The study was carried out in the Laboratory of Seed Analysis (LAS) of the Agricultural Sciences Center of the Federal University of Paraíba, Areia PB, Brazil. We used seeds of five cultivars of the bean obtained from a property located in the municipality of Queimadas - PB from the 2013/2014 crop. After the harvest, the seeds were taken to the laboratory and homogenized, packed in plastic bags and placed in a refrigerator for six months.

The variable analyzed were water content, and the germination, emergence, electrical conductivity, tetrazolium, first germination count and emergence, seedling length and dry mass, which compose the viability and vigor test.

We analyzed the water content by the greenhouse method, at $105 \pm 3{ }^{\circ} \mathrm{C}$ for 24 hours, using four replicates of $10 \mathrm{~g}$ of seeds for each cultivar, according to Brazil (2009).

The germination test was conducted using four replicates of 50 seeds previously treated with the fungicide captan, in the proportion of $240 \mathrm{~g} 100$ $\mathrm{kg}^{-1}$ of seeds for each cultivar. The seeds were distributeds on two sheets of paper towels, covered with a third paper towel and organized in a roll form. The paper was autoclaved at $120{ }^{\circ} \mathrm{C}$ for 120 minutes and moistened with distilled water for time your dry mass, with no subsequent addition of water. The seeds were placed to germinate at $25{ }^{\circ} \mathrm{C}$ with photoperiod 8/16 hours of light and dark. The counts were carrieds out from five to nine days after sowing (BRASIL, 2009).

We determined the first germination count in conjunction with the germination test, computing the percentage of normal seedlings on the fifth day after sowing (BRASIL, 2009).

The index of the speed of germination was carrieds out with the germination test by the daily counts of normal seedlings, from the fifth to the ninth day after sowing, at the same time every day. The index was calculated using the formula proposed by Maguire (1962).

The seedling length was measured following the procedures described by Nakagawa (1999), adapted from AOSA (1983). We used four replicates with 20 seeds for each cultivar of Phaseolus lunatus. The germinating paper towel was previously moistened with distilled water in the amount equivalent to 3.0 times its dry mass. A line was drawn in the upper third of the paper, in the longitudinal direction, the seeds were alternately positioned, and the micropyle was facing the bottom of the paper. After the sowing, the rolls were prepared, placed in plastic bags and positioned vertically in the Biological Oxygen Demand (B.O.D) germinator, regulated at a regime of constant temperature of $25{ }^{\circ} \mathrm{C}$ with photoperiod 8/16 hours of light and dark, using daylight fluorescent lamps $(4 \times 20 \mathrm{~W})$ for nine days. After the nine days, we measured the normal seedlings (primary and hypocotyl roots) using a ruler, and the mean seedling results were expressed in centimeters.

Dry mass of seedlings: the seedlings previously measured after removal of the cotyledons packed in paper bags of the Kraft type, taken to an air circulation oven at $65{ }^{\circ} \mathrm{C}$ until reaching a constant weight. After this period, the samples were removed placed in a desiccator and weighed with a precision of $0.0001 \mathrm{~g}$, determining the total dry mass of the seedlings ( $\mathrm{g}$ seedling ${ }^{-1}$ ) (NAKAGAWA, 1999).

For seedling emergence, we used four replications of 25 seeds of each cultivar were used for field emergence, divided into four blocks, and sown in beds with furrows of 1.0 meter in length and spaced at $5 \mathrm{~cm}$ with a depth of twice the size of the seed. The counts were performed from the fifth to the twenty-first day after sowing, and the results were expressed as a percentage.

We used four subsamples with 50 seed to measure the electrical conductivity of each cultivar. The samples were weighed in a precision balance of $0.0001 \mathrm{~g}$, placed in plastic cups containing $75 \mathrm{~mL}$ of deionized water and kept in Biological Oxygen Demand (B.O.D.) germinator, regulated at a constant temperature of $25{ }^{\circ} \mathrm{C}$ for 24 hours. The reads were realized through a conductivity meter and the results were expressed in $\mu S \mathrm{~cm}^{-1} \mathrm{~g}^{-1}$ of seeds (KRZYZANOWSKI; VIEIRA, 1999).

For tetrazolium tests, the Phaseolus lunatus seeds were submitted to preconditioning, which consisted of the pre-soaking of the seeds between two sheets of paper towel moistened with water, at a quantity equivalent to 3.0 times the dry mass of the germinating paper, regulated at $25{ }^{\circ} \mathrm{C}$ for 18 hours. The teguments were then removed avoiding damages to the embryos, and the seeds were submerged in a solution of 2,3,5-triphenyl chloride of tetrazolium ( $\mathrm{pH} 6.5$ to 7.0 ), in the concentration of $0,25 \%$ for three hours of soaking in a regulated oven at $40{ }^{\circ} \mathrm{C}$ in the dark (KRZYZANOWSKI; VIEIRA, 1999). The seeds were evaluated as viable or non-viable. 
The experimental design was completely random, for laboratory tests with four replicates, except for the tetrazolium test that was performed with two replicates for each cultivar. For the emergency test, we used a randomized blocks design, and the averages obtained in all the tests were submitted to the Scott-Knott test, at 5\% probability.

\section{RESULTS AND DISCUSSION}

We found a decrease in water content on the varieties Branca and Rosinha, while the varieties Cearense, Orelha de Vó and Roxinha increased the water content during the study. The Rosinha variety showed the higher water content variation between the initial and final analyze. We verified a significant difference from the cultivars Cearense and Rosinha from the other cultivars at the final (Table 1).

Table 1. Content water initial (CI) and final (CF) of seeds cultivars lima-bean.

\begin{tabular}{|c|c|c|}
\hline \multicolumn{3}{|c|}{ Content water (\%) } \\
\hline Cultivars & CI & $\mathrm{CF}$ \\
\hline Branca & $15.8 \mathrm{a}$ & $14.9 \mathrm{a}$ \\
\hline Cearense & $11.8 \mathrm{~b}$ & $14.1 \mathrm{~b}$ \\
\hline Orelha de Vó & $14.5 \mathrm{a}$ & $15.6 \mathrm{a}$ \\
\hline Rosinha & $16.3 \mathrm{a}$ & $13.6 \mathrm{~b}$ \\
\hline Roxinha & $12.7 \mathrm{~b}$ & $15.2 \mathrm{a}$ \\
\hline CV (\%) & 9.9 & 6.1 \\
\hline
\end{tabular}

*Averages followed by the same letter in the columns do not differ by Scott-Knott's test at $5 \%$ probability.

CV (coefficient of variation).

The water contents are an important aspect to carry out the tests, since the uniformity of water content of seeds in different lots is fundamental for the standardization of evaluations and obtaining consistent results (KRZYZANOWSKI; VIEIRA, 1999). Phaseolus lunatus requires a lower water content, which is more resistant to heat due to rusticity (SOTO et al., 2008).

About the germination and vigor, determined by the tests of the first count, germination speed index and dry mass of seedlings, we verified that the seeds of the cultivar Roxinha demonstrated the best performance in all evaluated variables, while the seeds of the cultivar Cearense showed the worst condition (Table 2). The cultivars have some different characteristics and, consequently, the effects of environmental conditions can cause variation during the cultivation phase, maturation until harvest.

Table 2. Germination (G), first germination count (FCG), germination speed index (ISG), seedling length (SL) and dry mass of seedlings (MDS) from the seed of lima-bean cultivars.

\begin{tabular}{lcclll}
\hline Cultivares & G $(\%)$ & FCG $(\%)$ & ISG & SL $(\mathrm{cm})$ & MDS $(\mathrm{g})$ \\
\hline Branca & $99 \mathrm{a}$ & $99 \mathrm{a}$ & $9.6 \mathrm{a}$ & $21.0 \mathrm{~b}$ & $0.077 \mathrm{a}$ \\
Cearense & $81 \mathrm{~b}$ & $81 \mathrm{a}$ & $8.1 \mathrm{~b}$ & $13.3 \mathrm{c}$ & $0.040 \mathrm{~b}$ \\
Orelha de Vó & $100 \mathrm{a}$ & $100 \mathrm{a}$ & $9.9 \mathrm{a}$ & $20.5 \mathrm{~b}$ & $0.085 \mathrm{a}$ \\
Rosinha & $99 \mathrm{a}$ & $99 \mathrm{a}$ & $9.9 \mathrm{a}$ & $10.9 \mathrm{c}$ & $0.020 \mathrm{~b}$ \\
Roxinha & $100 \mathrm{a}$ & $100 \mathrm{a}$ & $9.9 \mathrm{a}$ & $25.8 \mathrm{a}$ & $0.067 \mathrm{a}$ \\
\hline CV $(\%)$ & 2.4 & 2.4 & 2.4 & 14.8 & 24.5 \\
\hline
\end{tabular}

*Averages followed by the same letter in the columns do not differ by Scott-Knott's test at $5 \%$ probability.

$\mathrm{CV}$ (coefficient of variation).

In cultivars of Vigna unguiculata (L.) Walp, it was observed that germination and seedling emergence percentages were similar and that there are often differences in germination speed and seedling emergence leading to differences in vigor between them (MARCARELLO et al., 2012).
We do not observe a significant difference between the cultivars of Phaseolus lunatus for the variables percentage and speed of emergence, and the dry mass of the seedlings (Table 3). For the first emergency count, there was no statistical difference between the cultivars Roxinha and Rosinha, which also showed the best results in all the tests, except 
for the length of seedlings. In this case, probably there were degenerative transformations that led to the rapid consumption of seed reserves at the beginning of the germination process, resulting in a smaller length of the seedlings. However, all cultivars showed a good performance in field conditions.

Table 3. Emergency (E), first emergency count (FCE), emergency speed index (ISE), length (L) and dry mass of seedlings (MDS) of lima bean.

\begin{tabular}{llllll}
\hline Cultivars & $:(\%)$ & CE $(\%)$ & iE & $(\mathrm{cm})$ & [DS $(\mathrm{g})$ \\
\hline Branca & $+\mathrm{a}$ & $5 \mathrm{~cd}$ & $5.9 \mathrm{a}$ & $7.9 \mathrm{~b}$ & $60 \mathrm{a}$ \\
Cearense & $7 \mathrm{a}$ & $3 \mathrm{bc}$ & $7.9 \mathrm{a}$ & $7.5 \mathrm{a}$ & $68 \mathrm{a}$ \\
Orelha de Vó & $5 \mathrm{a}$ & $5 \mathrm{~d}$ & $7.9 \mathrm{a}$ & $7.9 \mathrm{a}$ & $87 \mathrm{a}$ \\
Rosinha & $5 \mathrm{a}$ & $76 \mathrm{ab}$ & $1.2 \mathrm{a}$ & $23.3 \mathrm{ab}$ & $63 \mathrm{a}$ \\
Roxinha & $5 \mathrm{a}$ & $5 \mathrm{a}$ & $5.4 \mathrm{a}$ & $5.2 \mathrm{c}$ & $67 \mathrm{a}$ \\
\hline CV $(\%)$ & 5.3 & 3.4 & 3.1 & 2.5 & 2.74 \\
\hline
\end{tabular}

*Averages followed by the same letter in the columns do not differ by Scott-Knott's test at $5 \%$ probability.

$\mathrm{CV}$ (coefficient of variation).

To evaluate the vigor of cultivars, the measure of the germination speed and the emergence of seedlings in field or greenhouse minimizes the adverse conditions that occur during germination and establishment of seedlings (STEINER et al., 2009). The slow emergence of seedlings is often associated with low vigor seeds producing smaller plants when compared to those produced by high vigor seeds (SANTOS et al., 2005).

The tetrazolium test was a rapid method for evaluating the seeds through the reaction of the salt 2,3,5-triphenyl chloride tetrazolium chloride with the living tissues of the seeds, while the electrical conductivity test demonstrates the degradation of the seeds through the release of exudates. Thus, it was observed higher vigor of the seeds of the cultivars Roxinha, Rosinha, Branca, and Orelha de Vó. Those cultivars demonstrated that there was a greater percentage of living tissues and a lower electrical conductivity when compared with the cultivar Cearense. A promising alternative for $P$. lunatus seeds would be the tetrazolium test because it demonstrates precision and rapidity in determining the vigor (Table 4).

Table 4. Tetrazolium test and electrical conductivity test on lima-bean cultivar seeds.

\begin{tabular}{llc}
\hline Cultivars & Tetrazolium test & Conductivity $\left(\mu \mathrm{S} \mathrm{cm}^{-1} \mathrm{~g}^{-1}\right)$ \\
\hline Branca & $30 \mathrm{~b}$ & $0.54 \mathrm{c}$ \\
Cearense & $6 \mathrm{~d}$ & $0.62 \mathrm{c}$ \\
Orelha de Vó & $29 \mathrm{~b}$ & $1.07 \mathrm{c}$ \\
Rosinha & $14 \mathrm{c}$ & $41.53 \mathrm{a}$ \\
Roxinha & $46 \mathrm{a}$ & $31.91 \mathrm{~b}$ \\
\hline $\mathrm{CV}(\%)$ & 5.4 & 15.1 \\
\hline Averages followed by the same letter in the columns do not differ by Scott-Knott's test at 5\% probability. \\
CV (coefficient of variation).
\end{tabular}

The most sensitive tests to determine the stage of seed deterioration are those that measure the activity of certain enzymes associated with the degradation of the reserves and/or biosynthesis of new tissues (CARVALHO et al., 2000). Therefore, the electrical conductivity was less sensitive to detect differences than the tetrazolium test. The electrical conductivity is the demonstration of the leached exudates of the seeds, since the greater its value, the lower the vigor, possibly due to the losses of the integrity of the cell membranes, i.e., damaged cells, poorly structured membranes, loss of cell constituents (BINOTTI et al., 2008). Still, according to Vieira et al. (1996), the electrical conductivity tests are significantly influenced by the genotype/cultivar factor.

The electrical conductivity test was effective in separating seed lots of arugula (Eruca sativa Mill.), When 50 seeds were used in $50 \mathrm{~mL}$ of water for 4 hours at a temperature of $25^{\circ} \mathrm{C}$ (ALVES; SÁ, 2009). Also, the electrical conductivity test did not find significant differences among the bean varieties: TB 02-24, TB 02-07, SM 1107, SM 1810, CHC 01175, CHP 986620, LP 0890, LP 07-80, BRS, CNFP 10104, GEN P5-4-3-1, Gen Pr 14-2-3, BRS Valente and Pérola, Guapo 
Brilhante and Carioca (IAC) (MAMBRIN et al., 2015).

The viability and vigor of cowpea seeds by the tetrazolium test proved to be efficient when a direct water immersion preconditioning was used for 16 hours at $25{ }^{\circ} \mathrm{C}$ with a solution of tetrazolium in the concentration of $0.05 \%$, for 210 minutes at the temperature of $40{ }^{\circ} \mathrm{C}$ (RODRIGUES et al., 2015).

We can infer the following results: the tetrazolium test is efficient for evaluation of seed vigor of Phaseolus lunatus; the seeds of the cultivar Roxinha are of better physiological quality and the cultivar Cearense showed the worst quality; the electrical conductivity test is not recommended to evaluate seed vigor of $P$. lunatus cultivars.

\section{ACKNOWLEDGEMENTS}

Thanks to the Coordination for the Improvement of Higher Education Personnel (CAPES) for the granting to the Master's degree. To the trainees of the Laboratory of Analysis of Seeds of the Center of Agricultural Sciences - UFPB for the support in the conduction of this experiment.

RESUMO: Em qualquer cultura, para se ter uma elevada produtividade é indispensável à aquisição de sementes com alta qualidade fisiológica, mas para sementes de Phaseolus lunatus L., ainda ocorre deficiência em análises de viabilidade e vigor. Dessa forma, o objetivo neste trabalho foi avaliar a qualidade fisiológica das sementes de cultivares de Phaseolus lunatus por diferentes testes de vigor. A pesquisa foi realizada no Laboratório de Análise de Sementes do Centro de Ciências Agrárias da Universidade Federal da Paraíba, em Areia - PB, com sementes de cinco cultivares de Phaseolus lunatus (Branca, Orelha de Vó, Cearense, Rosinha e Roxinha). Para avaliação da qualidade fisiológica das sementes determinou-se o teor de água e realizou-se testes de viabilidade e vigor (germinação, emergência, condutividade elétrica, tetrazólio, primeira contagem de germinação e emergência, comprimento e massa seca de plântulas). O delineamento utilizado foi o inteiramente casualizado, com exceção dos testes realizados em campo, que foi em blocos ao acaso. O teor de água das sementes dos cultivares de feijão-fava não diferiu estatisticamente entre si, indicando que houve uniformidade na porcentagem de umidade. Não houve diferença significativa entre as sementes dos cultivares de feijão-fava quando avaliou-se a porcentagem e velocidade de emergência, bem como a massa seca de plântulas. Os resultados dos testes de tetrazólio e condutividade elétrica constatou-se maior viabilidade para as sementes do cultivar Roxinha, Branca, Cearense e Orelha de Vó quando comparadas com as da Rosinha, uma vez que houve um maior percentual de tecidos vivos e uma menor condutividade elétrica, respectivamente. As sementes do cultivar Roxinha são de melhor qualidade fisiológica e, o cultivar Cearense de pior qualidade; o teste de tetrazólio é recomendado para avaliação do vigor de sementes de cultivares de Phaseolus lunatus, enquanto, o teste de condutividade elétrica não é recomendado para avaliar o vigor das sementes dos cultivares de $P$. lunatus.

PALAVRAS-CHAVES: Análise de sementes. Tetrazólio. Condutividade elétrica.

\section{REFERENCES}

ALVES, C. Z.; SÁ, M. E. Teste de condutividade elétrica na avaliação do vigor de sementes de rúcula. Revista Brasileira de Sementes, Brasília, v. 31, n. 1, p. 203-215, 2009. https://doi.org/10.1590/S010131222009000100023

AZEVEDO, J. N.; FRANCO, L. J. D.; ARAÚJO, R. O. C. Composição química de sete variedades de feijãofava. Teresina. EMBRAPA Meio-Norte. 2003. 4p. (Comunicado Técnico.).

BHERING, M. C.; DIAS, D.C. F. S.; BARROS, D. I. Adequação da metodologia do teste de tetrazólio para avaliação da qualidade fisiológica de sementes de melancia. Revista Brasileira de Sementes, Pelotas, v. 27, n. 1, p. 176-182, 2005. https://doi.org/10.1590/S0101-31222005000100022 
BINOTTI, F. F. S.; HAGA, K. I.; CARDOSO, E. D.; ALVES, C. Z.; SÁ, M. E.; A.R.F. O. Efeito do período de envelhecimento acelerado no teste de condutividade elétrica e na qualidade fisiológica de sementes de feijão.

Acta Scientiarum: Agronomy, Maringá, v. 30, n. 2, p. 247-254, 2008.

https://doi.org/10.4025/actasciagron.v30i2.1736

BRAGA JUNIOR, J. M.; ROCHA, M. S.; BRUNO, R. L. A.; VIANA, J. S.; BELTRÃO, N. E. M. Teste de envelhecimento acelerado em sementes de mamona cultivar BRS-Energia. Revista Eletrônica de Biologia, Sorocaba, v. 4, n. 1, p. 88-101, 2011.

BRASIL. Ministério da Agricultura, Pecuária e Abastecimento. Regras para análise de sementes. Secretaria de Defesa Agropecuária. Brasília: MAPA/ACS, 2009. 395p.

CARVALHO, M. L. M.; VIEIRA, M. G. G. C.; PINHO, E. R. V. Técnicas moleculares em sementes. Biotecnologia, Ciência e Desenvolvimento, Brasília, v. 3, n. 17, p. 44-47, 2000.

FRANÇA NETO, J. B. Teste de tetrazólio para determinação do vigor de sementes. In: GUIMARÃES, W. N. R.; MARTINS, L. S. S.; SILVA, E. F.; FERRAZ, G. M.G; OLIVEIRA, F. J. Caracterização morfológica e molecular de acessos de feijão-fava (Phaseolus lunatus L.). Revista Brasileira de Engenharia Agrícola e Ambiental, Campina Grande, v. 11, n. 1, p. 37-45, 2007. https://doi.org/10.1590/S1415-43662007000100005

IBGE. (2013) SIDRA - sistema IBGE de recuperação automática. Rio de Janeiro: Instituto Brasileiro de Geografia e Estatística. Disponível em <http://www.sidra.ibge.gov. br>. Acesso em: 21jul. 2015.

KRZYZANOWSKI, F. C.; VIEIRA, R. D. Deterioração controlada. In: KRZYZANOSWKI, F. C.; VIEIRA, R. D.; FRANÇA NETO. J. B. Vigor de sementes: conceitos e testes. Londrina: ABRATES. 1999. Cap. 8.3. p. 110.

LOPES, A. C. A.; GOMES, R. L. F.; SILVA, R. N. O.; COSTA, E. M. R.; SOUSA, I. F. S.; SANTOS, J. O.; SOUSA, T. H. P.; SILVA, K. J. D. Diversidade genética. In: ARAÚJO, A. S. F.; LOPES, A. C. A.; GOMES, R. L. F. (Org.). A cultura do feijão-fava na Região Meio-Norte do Brasil. 1.ed. Teresina: EDUFPI, 2010. v. 1. p. $45-72$.

MAGUIRE, R. G. Reporting of objective color measurements. HortScience, Alexandria, v.27, n.12, p.12541555, 1992. https://doi.org/10.21273/HORTSCI.27.12.1254

MAMBRIN, R. B.; RIBEIRO, N. D.; HENNING, L. M. M.; HENNING, F. A.; BARKERT, K. A. Seleção de linhagens de feijão com base no padrão e na qualidade de sementes. Revista Caatinga, Mossoró, v. 28, n. 3, p. 147-156, 2015. https://doi.org/10.1590/1983-21252015v28n317rc

MARCARELLO, A.; YAMASHITA, O. M.; CARVALHO, M. A. C. Qualidade fisiológica de sementes de feijoeiro em função da aplicação foliar de cobalto e molibdênio. Global Science Technology, Virginia, v. 5, n. 2, p. 121-132, 2012.

MARTINS, C. C.; BOVI, M. L. A.; NAKAGAWA J. Qualidade fisiológica de sementes de palmiteirovermelho em função da desidratação e do armazenamento. Horticultura Brasileira, Botucatu, v. 25, n. 2, p. 188-192, 2007. https://doi.org/10.1590/S0102-05362007000200012

NAKAGAWA, J. Testes de vigor baseados no desempenho das plântulas. In: KRZYZANOWSKI, F. C.; VIEIRA, R. D.; FRANÇA NETO, J. B. (Ed.). Vigor de sementes: conceitos e testes. Londrina: ABRATES, 1999. p. 8.5-1-8.5.26.

PACHECO, M. V.; MATOS, V. P.; FERREIRA, R. L. C.; FELICIANO, A. L. P.; SILVAPINTO, K. M. Efeito de temperaturas e substratos na germinação de sementes de Myracrodruon urundeuva Fr. All. (Anacardiaceae). Revista Árvore, Viçosa, v. 30, n. 3, p. 359-367, 2006. https://doi.org/10.1590/S0100-67622006000300006 
RODRIGUES, A. P. M. S.; MENDONÇA JÚNIOR, A. F.; TORRES, S. B.; NARJARA WALESSA NOGUEIRA, N. W.; FREITAS, R. M. O. Teste de tetrazólio para avaliação da qualidade fisiológica de sementes de Vigna unguiculata (L.) Walp. Revista Ciência Agronômica, Fortaleza, v. 46, n. 3, p. 638-644, 2015.

SANTOS, C. M. R.; MENEZES, N. L.; VILLELA, F. A. Modificações fisiológicas e bioquímicas em sementes e feijão no armazenamento. Revista Brasileira de Sementes, Brasília, v. 27, n. 1, p. 104-114, 2005. https://doi.org/10.1590/S0101-31222005000100013

SANTOS, D. M. Variação espacial na dinâmica do banco de sementes em uma área de caatinga em Pernambuco durante três anos consecutivos. 2010. 70 f. Dissertação (Mestrado em Botânica) - Universidade Federal Rural de Pernambuco, Recife, 2010.

SANTOS, D.; CORLETT, F. M. F.; MENDES, J. E. M. F.; WANDERLEY JÚNIOR, J. S. A. Produtividade e morfologia de vagens e sementes de variedades de fava no Estado da Paraíba. Pesquisa Agropecuária Brasileira, Pelotas, v. 3, n. 10, p. 1407-1412, 2004. https://doi.org/10.1590/S0100-204X2002001000008

SOARES, C. A.; LOPES, A. C. A.; GOMES, R. L. F.; GÂNDARA, F. C. In: LOPES, A.C. A.; GOMES, R. L. F.; ARAUJO, A. S. F. A cultura do feijão-fava no Meio-Norte do Brasil. Teresina: EDUFPI, 2010. p. 239263.

SOTO, J. L. L.; CORRAL, J. A. R.; GONZÁLEZ, J. J. S.; ILDEFONSO, R. L. Adaptación climática de 25 especies de frijol silvestre (Phaseolus spp.) en la República Mexicana. Revista Fitotecnia Mexicana, Harbana, v. 28, n. 3, p. 211-230, 2008.

STEINER, F.; PINTO JUNIOR, A. S.; ZOZ, T.; GUIMARÃES, V. F.; DRANSKI, J. A. L.; RHEINHEIMER, A. R. Germinação de sementes de rabanete sob temperaturas adversas. Revista Brasileira de Ciências Agrárias, Recife, v. 4, n. 4, p. 430-434, 2009. https://doi.org/10.5039/agraria.v4i4a10

VIEIRA, R. D.; PANOBIANO, M.; LEMOS, L. B.; FORNASIEIRO FILHO, D. Efeito de genótipos de feijão e de soja sobre os resultados da condutividade elétrica de sementes. Revista Brasileira de Sementes, Brasília, v. 18, n. 2, p. 220-224, 1996. https://doi.org/10.17801/0101-3122/rbs.v18n2p220-224

VIEIRA, R. D.; PENARIOL, A. L; PERECIN, D.; PANOBIANCO, M. Condutividade elétrica e teor de água inicial das sementes de soja. Pesquisa Agropecuária Brasileira, Brasília, v. 37, n. 9, p. 1333-1338, 2002. https://doi.org/10.1590/S0100-204X2002000900018 